\title{
Peningkatkan Hasil Belajar IPA Melalui Puzzles Picture Game
}

\author{
Jul Trisadnaweka \\ SMP NEGERI 4 NGAWI
}

sadnaju163@gmail.com

\begin{abstract}
Abstrak
Tujuan penelitian ini adalah untuk meningkatkan hasil belajar IPA Melalui Permainan Puzzles Pictured Game.Subyek dalam penelitian ini adalah siswa Kelas VII H SMP Negeri 4 Ngawi Kecamatan Ngawi dengan jumlah siswa 28 orang terdiri dari 16 orang siswa laki-laki dan 12 orang siswa perempuan. Data yang diperoleh dianalisis dan dideskripsikan sesuai permasalahan yang ada dalam bentuk laporan hasil penelitian. Rancangan pembelajaran interaktif dan pemberian tugas kerja kelompok dilakukan validasi oleh guru.Prosedur penelitian ini dilakukan melalui empat langkah dalam setiap siklus penelitian, yaitu perencanaan (planing), tindakan (action), pengamatan (observation) dan refleksi (reflection) serta indikator kerja.Siklus kedua dilakukan mengacu pada siklus sebelumnya dengan menyempurnakan segala kekurangan yang ada pada siklus pertama tersebut.Hasil Penelitian pra siklus skor tercapai $67 \%$.nilai terendah 48 ,nilai tertinggi 76 ,rentang persen $6 \%$ tuntas 3 ,tidak tuntas 25 .Siklus I skor tercapai $73 \%$.nilai terendah 55,nilai tertinggi 81 ,rentang persen $9 \%$ tuntas 12 ,tidak tuntas 16 .siklus II skor tercapai $82 \%$.nilai terendah 62 ,nilai tertinggi 96 ,rentang persen $18 \%$ tuntas 22,tidak tuntas 6 siswa.Kesimpulan hasil penelitian yang telah dilaksanakan pada Kelas VII H Semester II SMP Negeri 4 Ngawi Kecamatan Ngawi Kabupaten Ngawi adalah Pembelajaran melalui Permainan Puzzles Pictured Game dapat meningkatkan hasil belajar siswa.
\end{abstract}

Kata Kunci : Hasil Belajar, Ilmu Pengetahuan Alam (IPA), Puzzles Picture Game

\section{PENDAHULUAN}

\section{Latar Belakang Masalah}

Guru merupakan salah satu faktor yang cukup bepengaruh langsung dalam peningkatan mutu tersebut. Guru merupakan jabatan yang dipilih berdasarkan prinsip-prinsip vokasional, dalam hal aspek psikologis menjadi faktor untuk melaksanakan tugas dan tanggung jawabnya sebagai pendidik (Oemar Hamalik, 2002). Peningkatan mutu pendidikan dasar dan menengah serta mutu pelajaran IPA disekolah menengah perlu perubahan pola fikir positif yang digunakan sebagai landasan pelaksanaan kurikulum.

Dalam kegiatan pembelajaran, guru mata pelajaran IPA menggunakan berbagai strategi yang menghendaki keterlibatan dan peran aktif siswa dalammelakukan pengamatan, meramal, menerapkan konsep dan mengkomunikasikannya. Aktivitas dan keterlibatan siswa secara utuh sangat penting agar kegiatan pembelajaran mencapai tujuan. Adanya aktivitas belajar siswa secara optimal akan menentukan tingkat pemahaman dan hasil belajar siswa. 
Pada masa lalu proses belajar mengajar untuk mata pelajaran IPA terfokus kepada guru dan kurang terfokus pada siswa. Akibatnya kegiatan belajar mengajar lebih ditekankan pada pengajaran dari pada pembelajaran. Kata pembelajaran dapat diartikan sebagai perubahan yang terjadi dalam kemampuan, sikap, atau perubahan tingkah laku siswa yang relatif permanen sebagai akibat dari pengalaman atau latihan. Perubahan kemampuan yang hanya sebentar dan kembali ke perilaku semula menunjukkan belum terjadi peristiwa pembelajaran, walaupun mungkin terjadi pengajaran. Tugas guru adalah membuat agar proses pembelajaran pada siswa berlangsung secara aktif, efektif, kreatif, menarik dan menyenangkan, dengan memperhatikan pendekatan sains, serta “ Learning to do, Learning to know, Learning to be and Learning to live together " (Depdiknas 2003).

Melihat kondisi lapangan di Kelas VII H Semester II pada SMP Negeri 4 Ngawi ,yakni melalui pengamatan langsung oleh penulis terlihat kurang terlibatnya siswa dalam pembelajaran Ilmu Pengetahuan Alam. Hal ini mengakibatkan hasil belajar yang rendah yaitu dengan nilai rata-rata hanya sebesar $67 \%$. Dari 28 siswa Kelas VII H hanya 3 orang (9\%) mencapai KKM yang ditetapkan sekolah yaitu 75.

Kondisi pembelajaran IPA yang demikian akan menimbulkan dampak kurang menggembirakan terhadap hasil belajar siswa, dan lebih jauh lagi dapat menimbulkan kesan tidak baik terhadap pembelajaran IPA seperti pengetahuan IPA hanyalah bersifat teoretis semata.

Dengan menyadari gejala-gejala atau kenyataan tersebut diatas, mendorong penulis untuk melakukan penelitian guna mengkaji peningkatan hasil belajar siswa dengan permainan gambar puzzle dalam pembelajaran IPA diKelas VII H SMP Negeri 4 Ngawi.

\section{Rumusan Masalah}

Bertitik tolak dari latar belakang masalah diatas, maka penulis merumuskan permasalahnnya sebagi berikut: Apakah Melalui Permainan Puzzles Pictured Game Dapat Meningkatkan Hasil Belajar IPA Pada Siswa Kelas VII H Semester II SMP Negeri 4 Ngawi?

\section{Tujuan Penelitian}

Untuk meningkatkan hasil belajar IPA pada siswa kelas VII H Semester II SMP Negeri 4 Ngawi Melalui Permainan Puzzles Pictured Game.

\section{Manfaat Penelitian}

Dilaksanakannya penelitian ini diharapkan dapat memberikan bermanfaat sebagai berikut:

\section{a. Bagi Siswa}

Meningkatkan aktifitas belajar siswa dan mempermudah mengingat serta memahami konsep-konsep IPA

b. Bagi Guru

Meningkatkan kemampuan guru dalam berkreasi dan berinovasi pada pembelajaran sehingga lebih efektif dan efisien dalam peranannya sebagai fasilitator dan mediator

c. Bagi Sekolah

Meningkatkan profesionalisme guru IPA di Sekolah menengah dengan menulis penelitian ilmiah yang memberikan solusi bagi permasalahan pembelajaran IPA.

d. Peneliti,

Sebagai kegiatan pengembangan profesi pendidik guna menambah pengalaman dalam melaksanakan tugas dimasa depan.

\section{KAJIAN TEORI}

\section{HASIL BELAJAR}

Hakekat Hasil Belajar

Darmansyah (2006) menyatakan bahwa hasil belajar adalah hasil penilaian terhadap kemampuan siswa yang ditentukan dalam bentuk angka. Dari pendapat di atas dapat disimpulkan bahwa yang dimaksud dengan 
hasil belajar adalah hasil penilaian terhadap kemampuan siswa setelah menjalani proses pembelajaran.

Hasil belajar merupakan suatu prestasi yang dicapai seseorang dalam mengikuti proses pembelajaran, dengan kata lain hasil belajar merupakan perubahan yang terjadi dalam diri individu yang belajar. Perubahan yang diperoleh dari hasil belajar adalah perubahan secara menyeluruh terhadap tingkah laku yang ada pada diri individu. Hasil belajar itu mencakup ranah kognitif, afektif dan psikomotor. Sesuai menurut Bloom yang dikutip Djaafar (2001) menyatakan hasil belajar dibagi dalam tiga ranah atau kawasan yaitu (1) Ranah Kognitif, (2) Ranah Afektif dan (3) Ranah Psikomotor.

Masing-masing ranah menghasilkan kemampuan tertentu. Hasil belajar ranah kognitif berorientasi kepada kemampuan "berpikir" yang mencakup kemampuan memecahkan suatu masalah. Hasil belajar ranah afektif berhubungan dengan perasaan, emosi, sistem nilai dan sikap hati-hati yang menunjukkan penerimaan atau penolakkan terhadap sesuatu. Sedangkan hasil belajar ranah psikomotorik yang berhubungan dengan anggota tubuh atau tindakan yang memerlukan koordinasi antara syaraf dan otak.

Menurut Gagne yang dikutip Djaafar (2001) hasil belajar merupakan kapabilitas atau kemampuan yang diperoleh dari proses belajar yang dapat dikategorikan dalam lima macam, yaitu: (1) informasi verbal, (2) keterampilan intelektual, (3) Strategi kognitif, (4) Sikap, dan (5). Keterampilan motorik. Hasil belajar dapat diperoleh dari interkasi siswa dengan guru atau interaksi siswa dengan lingkungan belajarnya yang sengaja dirancang dan direncanakan guru dalam perbuatan mengajar. Sudjana (2004) menyatakan hasil belajar yang dicapai siswa dipengaruhi oleh dua faktor utama yaitu faktor dari dalam diri dan dari lingkungan

Selanjutnya Winataputra (2007) lebih menjelaskan, hasil belajar berupa perilaku atau tingkah laku. Seseorang belajar akan berubah atau bertambah perilaku, baik yang berupa pengetahuan, keterampilan motorik atau penguasan nilai-nilai (sikap)

\section{Ilmu Pengetahuan Alam (IPA)}

IPA diperlukan dalam kehidupan sehari-hari untuk memenuhi kebutuhan manusia melalui pemecahan masalah-masalah yang dapat diidentifikasikan. Penerapan IPA perlu dilakukan secara bijaksana agar tidak berdampak buruk terhadap lingkungan. Di tingkat sekolah menengah diharapkan ada penekanan pembelajaran Salingtemas (Sains, lingkungan, teknologi dan masyarakat) yang diarahkan pada pengalaman belajar untuk merancang dan membuat suatu karya melalui penerapan konsep IPA dan kompetensi bekerja ilmiah secara bijaksana.

Pembelajaran IPA sebaiknya dilaksanakan secara inkuiri ilmiah (scientific inquiry) untuk menumbuhkan kemampuan berfikir, bekerja dan bersikap ilmiah serta mengkomunikasikannya sebagai aspek penting kecakapan hidup. Oleh karena itu pembelajaran IPA di SMP menekankan kepada pemberian pengalaman belajar secara langsung melalui penggunaan dan pengembangan keterampilan proses dan sikap ilmiah.

Sesuai dengan Peraturan Menteri Pendidikan Nasional RI Nomor 22 Tahun 2006 tentang Standar Kompetensi dan Kompetensi Dasar tingkat Sekolah Menengah, ruang lingkup bahan kajian IPA untuk meliputi aspek-aspek sebagai berikut:

a. Makhluk hidup dan proses kehidupan, yaitu manusia, hewan, tumbuhan dan interaksinya dengan lingkungan, serta kesehatan.

b. Benda/materi, sifat-sifat dan kegunaanya meliputi: cair, padat dan gas.

c. Energi dan perubahannya meliputi: gaya, bunyi, panas, magnet, listrik, cahaya dan pesawat sederhana. 
d. Bumi dan alam semesta meliputi: tanah, bumi, tata surya dan benda-benda langit lainya.

4. Implementasi pembelajaran IPA

Setelah mengenal empat prinsip pembelajaran IPA dan siap mengimplementasikannya, ada beberapa hal yang perlu dipertimbangkan untuk membuat siswa belajar dengan baik, yaitu lingkungan belajar non fisik. Lingkungan belajar non fisik adalah keadaan psikologis di sekitar siswa yang diciptakan oleh guru secara sengaja untuk mendorong siswa belajar.

\section{PUZZLES PICTURE GAME}

Tinjauan Tentang Permainan Gambar Puzzle

Sebelumnya kita telah mengetahui bahwa permainan dalam pembelajaran seperti permainan gambar puzzle adalah salah satu cara yang dapat menarik karena cara ini dapat memotivasi siswa untuk menyukai pelajaran IPA. Puzzle Picture menurut Wojowasito dan Poerwadaminta (2004) adalah teka-teki berupa gambar yang dapat merangsang anak untuk berfikir. Hanya saja sebelum kita mengajarkannya di depan kelas, guru harus mengetahui strategi yang tepat untuk mengajarkannya. Sebelum kita mengajar harus terlebih dahulu melakukan persiapan. Salah satunya adalah mengetahui keadaan siswa yang akan diajar dan mempersiapkan strategi yang tepat serta menarik untuk menghadapinya.

Ada beberapa yang diharapkan siswa setelah guru memasuki ruangan kelas dan guru nantinya diharapkan dapat memenuhi hal tersebut sehingga siswa tetap termotivasi untuk belajar. Menurut Ronald. W. Luce (dalam Suryanto, 2002) hal yang diinginkan siswa tersebut adalah: (1) Siswa ingin kebutuhan pribadinya terpenuhi dalam belajar. Mereka ingin bakat dan kemampuannya dihargai oleh guru dalam kelas. (2) Siswa ingin gurunya benar-benar menghargai mereka sebagai "manusia", yang peduli mereka bukan hanya guru yang selalu ingin mengevaluasi. (3) Siswa ingin ditantang dengan pelajaran bukan menjatuhkan mereka. (4) Siswa ingin guru menjaga dan selalu mendukung mereka mengikuti perkembangnya secara individu. (5) Siswa menyukai guru yang bisa menyesuaikan diri dengan mereka, humoris dan bisa mengerti humor mereka. (6) Siswa menyukai cara menerangkan yang jelas dan lengkap serta memberikan contoh-contoh yang konkrit.

Lana Becker dan Kent N. Schneider (dalam Suryanto, 2002) menyarankan beberapa peraturan agar tetap fokus dan termotivasi dalam belajar yaitu: a) menjelaskan kepada siswa untuk mempelajari materi yang akan diajarkan, b) menyediakan media visual untuk mendukung materi pelajaran, c) menerangkan materi pelajaran secara logis dan dapat diterapkan, d) memberikan kegiatan di dalam kelas segera setelah materi tersebut diajarkan, e) membantu siswa untuk menghubungkan pelajaran yang lalu dengan pelajaran yang sedang diajarkan, f) menghargai siswa ketika proses belajar mengajar berlangsung. Apabila siswa merasa dihargai mereka akan memberikan usaha terbaiknya, dan g) memberikan standar belajar yang tinggi.

Berdasarkan paparan di atas dapat disimpulkan bahwa memberikan materi pelajaran melalui permainan gambar puzzle bertujuan untuk menarik perhatian siswa dan menjaga motivasinya untuk belajar IPA dan dapat mengembangkan dalam kehidupan sehari-hari.

\section{METODOLOGI PENELITIAN}

\section{Setting Penelitian}

Penelitian ini bertempat di SMP Negeri 4 Ngawi yang terletak di jalan Trunojoyo 48 Ngawi, Jawa Timur, dengan alasan penulis bertugas di sekolah tersebut.

Penelitian ini berlangsung selama \pm 4 (empat) bulan yang dimulai pada bulan Januari-April 2018 Semester II tahun pelajaran 2017-2018 dengan alasan bertepatan dengan materi yang penulis ajarkan.

\section{Subyek Penelitian}

Sebagai subyek dalam penelitian ini adalah siswa Kelas VII H SMP Negeri 4 Ngawi 
Kecamatan Ngawi dengan jumlah siswanya adalah 28 orang terdiri dari 16 orang siswa laki-laki dan 12 orang siswa perempuan. Situasi kelas yang dijadikan subjek penelitian cukup memadai.

\section{Sumber Data}

Sumber data yang digunakan dalam penelitian ini adalah hasil tes formatif siklus I dan siklus II serta catatan pengamatan lapangan pada kondisi awal, siklus I dan siklus II serta hasil pengamatan kelas.

\section{Teknik dan Alat Pengumpulan Data}

Teknik pengumpulan data dilakukan dengan cara observasi.

Instrument yang digunakan untuk melaksanakan penelitian adalah

(1) dokumen observasi tindakan berupa catatan terhadap siswa dalam pembelajaran IPA selama pembelajaran berlangsung, dokumen tindakan analisis setiap akhir siklus.

(2) lembaran test berupa soal yang digunakan untuk melihat penguasaan konsep -konsep materi pembelajaran tentang sistem pencernaan manusia yang sudah diajarkan.

\section{Analisis Data}

Data yang diperoleh dianalisis dan dideskripsikan sesuai permasalahan yang ada dalam bentuk laporan hasil penelitian. Rancangan pembelajaran interaktif dan pemberian tugas kerja kelompok dilakukan validasi oleh guru.

\section{Indikator Keberhasilan}

Penelitian ini dianggap berhasil jika telah memenuhi indikator pencapaian hasil sebagai berikut rata-rata prosentase

\begin{tabular}{|l|l|l|l|}
\hline $\mathbf{8 1 \%}$ & $\sim$ & $\mathbf{9 0 \%}$ & Baik \\
\hline $\mathbf{9 1 \%}$ & $\sim$ & $\mathbf{1 0 0 \%}$ & Sangat Baik \\
\hline
\end{tabular}

\section{Prosedur Penelitian}

Prosedur penelitian ini dilakukan melalui empat langkah dalam setiap siklus penelitian, yaitu perencanaan (planing), tindakan (action), pengamatan (observation) dan refleksi (reflection) serta indikator kerja.Siklus kedua dilakukan mengacu pada siklus sebelumnya dengan menyempurnakan segala kekurangan yang ada pada siklus pertama tersebut.

\section{HASIL PENELITIAN DAN PEMBAHASAN \\ Deskripasi Kondisi Awal}

Sebelum dilakukan tindakan, proses belajar mengajar untuk mata pelajaran IPA masih terfokus kepada guru dan kurang terfokus pada siswa.Akibatnya kegiatan belajar mengajar lebih ditekankan pada pengajaran dari pada pembelajaran

Kondisi tersebut menjadikan aktifitas belajar siswa Kelas VII H cenderung rendah dan monoton, ditandai dengan siswa lebih senang diceramahi, siswa sedikit sekali yang mau bertanya, sedikit siswa yang mampu menjawab pertanyaan, dan contoh-contoh materi pelajaran yang diberikan guru masih kurang terkait dengan lingkungan kehidupan siswa seharihari. Hal inilah yang menyebabkan nilai ratarata hasil belajar IPA menjadi rendah yaitu $67 \%$ seperti tertera pada tabel di bawah ini.

Data Hasil Belajar Kondisi Awal

\begin{tabular}{|l|l|}
\hline PRA SIKLUS \\
\hline$\%$ SKOR TERCAPAI & $67 \%$ \\
\hline NILAI TERENDAH & 48 \\
\hline NILAI TERTINGGI & 76 \\
\hline RENTANG PERSEN & $6 \%$ \\
\hline TUNTAS & 3 \\
\hline TIDAK TUNTAS & 25 \\
\hline
\end{tabular}

\section{Deskripsi Tindakan dan Hasil Penelitian Siklus I}

Hasil belajar IPA yang ditunjukkan melalui hasil tes akhir siklus I, terdapat 16 siswa yang memiliki nilai dibawah 75 dengan nilai terendah 55 dan tertinggi 81 , rata-rata $73 \%$.

Berikut hasi belajar setelah diberikan tindakan pada siklus I secara lengkap dapat penulis paparkan pada tabel di bawah ini. 
Data Hasil Belajar Siklus I

\begin{tabular}{|l|l|}
\hline SIKLUS I \\
\hline \% SKOR TERCAPAI & $73 \%$ \\
\hline NILAI TERENDAH & 55 \\
\hline NILAI TERTINGGI & 81 \\
\hline RENTANG PERSEN & $9 \%$ \\
\hline TUNTAS & 12 \\
\hline TIDAK TUNTAS & 16 \\
\hline
\end{tabular}

Berdasarkan hasil refleksi di atas, maka perlu dicarikan alternatif perbaikan dari permasalahan yang timbul dengan menyempurnakan tindakan yang dipilih dan meningkatkan keadaan yang telah baik pada siklus I.

\section{Deskripsi Tindakan dan Hasil Penelitian Siklus II}

Hasil belajar siswa yang ditunjukkan dengan nilai siswa hasil tes pada akhir siklus II ternyata dari 28 jumlah siswa, ada 6 orang siswa yang memperoleh nilai dibawah 75 , skor terendah 62 dan tertinggi 96 dengan nilai ratarata $82 \%$.

Berikut hasi belajar setelah diberikan tindakan pada siklus II secara lengkap dapat penulis paparkan pada tabel di bawah ini.

Data Hasil Belajar Siklus II

\begin{tabular}{|l|l|}
\hline \multicolumn{2}{|l|}{ SIKLUS II } \\
\hline$\%$ SKOR TERCAPAI & $82 \%$ \\
\hline NILAI TERENDAH & 62 \\
\hline NILAI TERTINGGI & 96 \\
\hline RENTANG PERSEN & $18 \%$ \\
\hline TUNTAS & 22 \\
\hline TIDAK TUNTAS & 6 \\
\hline
\end{tabular}

Berdasarkan hasil observasi di atas, maka peneliti beserta pengamat memutuskan unutk menghentikan penelitian ini pada siklus II karena sudah dianggap berhasil dan KKM yang ditetapkan yaitu 75 sudah tercapai. Namun demikian peneliti berusaha terus untuk lebih meningkatkan hasil belajar dengan penerapan inovasi-inovasi baru pada proses pembelajaran.

\section{Pembahasan Tiap Siklus dan Antar Siklus}

Hasil tes akhir belajar pada kondisi awal sebelum diberikan tindakan hanya mencapai nilai rata-rata $67 \%$ dan 3 siswa yang sudah mencapai KKM. Pada tes akhir belajar siklus I mulai adanya peningkatan yaitu rata-rata nilai siswa 73\% dengan ketuntasan belajar 12 siswa di atas KKM. Ini berarti belum mencapai KKM yang sudah ditetapkan yaitu 75 . Oleh sebab itu peneliti perlu melanjutkan siklus II dengan memperbaiki proses pembelajaran sesuai dengan hasil refleksi kegiatan siklus pertama.

Pada siklus kedua rata-rata nilai siswa sudah mencapai $80 \%$, ini menunjukkan bahwa proses pembelajaran siklus II sudah menunjukkan peningkatan yang sangat tajam, dimana ketuntasan belajar sudah dicapai bahkan melebihi target yang ditetapkan. Semua ini disebabkan oleh keterlibatan dan kesungguhan siswa dalam berdiskusi semakin tinggi. Peneliti/guru sudah berhasil memotivasi siswa sehingga minatnya semakin baik dalam diskusi untuk menyelesaikan tugas yang diberikan.

\section{SIMPULAN DAN SARAN Simpulan}

Dari pencapian hasil belajar yang sudah dipaparkan pada bab sebelumnya, peneliti dapat menyimpulkan bahwa hasil penelitian yang telah dilaksanakan pada Kelas VII $\mathrm{H}$ Semester II SMP Negeri 4 Ngawi Kecamatan Ngawi Kabupaten Ngawi adalah sebagai berikut:

1. Pembelajaran melalui Permainan Puzzles Pictured Game dapat meningkatkan pemahaman konsep pada mata pelajaran IPA.

2. Melalui media gambar puzzle dapat meningkatkan kemampuan siswa dalam berkomunikasi dan kerjasama antar siswa serta hasil belajarnya. 
3. Guru mendapat kemudahan dalam berkreasi dan berinovasi pada pembelajaran, lebih efektif dan efisien untuk mencapai tujuan pembelajaran.

\section{Saran}

Mengacu kepada hasil penelitian, pembahasan dan kesimpulan maka dapat diajukan saran-saran sebagai berikut:

1. Pembelajaran IPA agar diupayakan lebih mengutamakan mendorong siswa secara aktif

2. Permainan gambar puzzle dapat dijadikan salah satu alternatif bagi guru untuk meningkatkan pemahaman konsep bagi siswa dalam mata pelajaran IPA.

3. Sebaiknya guru menyiapkan beberapa alternatif gambar yang menarik untuk digunkan dalam proses pembelajaran.

\section{DAFTAR PUSTAKA}

Dimyati. (2002). Belajar dan Pembelajaran. Jakarta: Rineka Cipta

Iskandar, Srini. (2002). Pendidikan Ilmu Pengetahuan Alam. Jakarta: Depdikbud.

Indrawati. (2008). Karakteristik Pembelajaran IPA di Sekolah Menengah. Jakarta: Erlangga.

Suryanto. (2002). Pembelajaran Dengan Permainan Gambar Puzzle. Jakarta: Rineka Cipta.

Trianto. (2007). Prisip-Prinsip Pembelajaran IPA Jakarta: Erlangga

Winataputra. (2007). Beberapa Penyebab Rendahnya Hasil belajar. Bandung Sinar Baru

Wojowasito, Poerwadaminta. (2004). Belajar Sambil Bermain. Jakarta: Rineka Cipta

Zamroni. (2003). Paradigma Pendidikan Masa Depan. Jakarta: Direktorat Jendral Pendidikan Dasar dan Menengah. Depdiknas. 